\author{
DE DE GRUYTER \\ OPEN \\ 10.1515/aucft-2016-0011
}

\title{
EVALUATION OF AGRO-INDUSTRIAL CO-PRODUCTS AS SOURCE OF BIOACTIVE COMPOUNDS: FIBER, ANTIOXIDANTS AND PREBIOTIC
}

\author{
Annel M HERNÁNDEZ-ALCÁNTARA*, Alfonso TOTOSAUS**, M. \\ Lourdes PÉREZ-CHABELA*1 \\ *Biotechnology Department. Universidad Autónoma Metropolitana
Iztapalapa, Mexico City, Mexico.
${ }^{* *}$ Food Science Lab \& Pilot Plant. Tecnológico Estudios Superiores \\ Ecatepec, Mexico.
}

\begin{abstract}
Agro-industrial co-products derived of fruit processing represents an important source of bioactive compounds as fiber, antioxidants and prebiotics. The objective of this work was to determine the content of fiber, antioxidant capacity and prebiotic activity of three flours obtained from commonly co-products (banana peel, apple peel, and carrot bagasse). The results showed a higher total fiber content in carrot bagasse, and lower in apple peel. Significantly differences were found in antioxidant activity. Fruit co-products flours were a suitable carbon source increasing specific growth rate with a reduction in duplication time as compared to glucose. The prebiotic activity was positive in the three co-products, all flours survived at $\mathrm{pH} 1.0$ and showed resistance to simulated gastric acid for about $60 \mathrm{~min}$. Banana peel, apple peel and carrot bagasse showed to be a good source of bioactive compounds as fiber and antioxidants and can be used as prebiotics for lactic acid bacteria.
\end{abstract}

Keywords: agroindustrial co-products, fiber, antioxidants, prebiotic.

\section{INTRODUCTION}

The processing of fruits results in high amounts of waste materials as peels, seeds, etc. Disposal of these materials represents a problem of contamination and normally these products are utilized as animal feed or fertilize (Oreopoulou and Tzia, 2007). In the last years the valorisation of agricultural co-products is receiving more attention, co-products contain valuable

1 Corresponding author. Mailing address. Lourdes Perez-Chabela. Biotechnology Department, Universidad Autonoma Metropolitana Iztapalapa. Av. San Rafael Atlixco 86, Mexico City 09340, Mexico. E-mail: 1pch@xanum.uam.mx 
substances, such as pigments, sugars, organic acids, flavours and bioactive compounds with antioxidant activity; they are good sources of dietary fiber (Martínez et al., 2012). These co-products could be converted into commercial products, either as raw materials for secondary processes (intermediate food ingredients) as operating supplies, or as ingredients of new products (Sánchez-Zapata et al., 2009).

Many agricultural co-products are rich in dietary fibers. The term dietary fiber refers of the "remnants of edible plant cells, polysaccharides, lignin and associated substances resistant to digestion by the alimentary enzymes of humans" (Trowell, 1974). The dietary fiber decrease faecal transit time through the bowel (Marlett et al., 2002). Raw materials to produce fruit fiber are available in large quantities and are more or less a by-product of the processing of fruits to juice or puree (Larrauri, 1999).

Phenolic compounds present in plants tissues are an essential part of the human diet, and are of considerable interest due to their antioxidant properties. Fruits, vegetables and beverages are the major sources of phenolic compounds in the human diet. The food and agricultural products processing industries generate substantial quantities of phenolic rich co-products, which could be valuable natural sources of antioxidants (Balasundram et al., 2006). Epidemiologic studies have clearly shown that diets rich in plant foods protect humans against degenerative diseases such as cancer and cardiovascular diseases (Manach et al., 2005). Plant polyphenol composition is highly variable both qualitatively and quantitatively, for example, flavanols are the major polyphenols (65-85\%) in apples (Cheynier, 2005).

Prebiotics are one of the most important functional foods. A prebiotic is a selectively fermented ingredient that allows specific changes, both in the composition and/or activity in the gastrointestinal microflora, conferring healthy benefits to the host (Gibson et al., 2004, Roberfroid, 2007). Nonetheless, the criteria necessary to consider a carbohydrate as a prebiotic are: 1) resistance to gastric acidity, hydrolysis by mammalian enzymes, and gastrointestinal absorption; 2) fermentation by intestinal microflora; and 3) selective stimulation of the growth and/or activity of those intestinal bacteria that contribute to health and well-being (Gibson et al., 2004). Most prebiotics and prebiotic candidates identified today are non-digestible oligosaccharides; they are obtained either by extraction from plants (Delzenne and Roberfroid, 1994).

The objective of this work is to determine the total fiber content, antioxidant capacity and prebiotic activity for three ingredients obtained from agro industrial co-products: banana peel, apple peel and carrot bagasse, as a source of bioactive compounds. 


\section{MATERIALS AND METHODS}

\section{Ingredients}

Banana peel (Musa sapientum), apple peel (Malus domestica) and carrot (Daucus carota L.) bagasse were obtained from local fruit processing establishments in Mexico City. Collected peels and bagasse were transported to the lab in plastic boxes and kept under refrigerated storage $\left(5 \pm 1{ }^{\circ} \mathrm{C}\right)$ until processing. Peels were washed with tap water, cut in small $2 \times 2 \mathrm{~cm}$ cubes and dried at $60{ }^{\circ} \mathrm{C}$ until constant weight was obtained. Bagasse was uniformly distributed to dry process at same conditions. Dry materials were sieved successively after ground in different number sieves $(100,80,50$ and 20) to obtain a regular powder named flour and stored in dark containers.

\section{Fiber Composition, total phenolic compounds and antioxidant capacity}

The total, soluble and insoluble dietary fibers were determined by the enzymatic gravimetric method, AOAC Official Method No. 991.43 (AOAC, 1999).

Polyphenols were extracted employing an organic solvent to macerate one $g$ of flour in the corresponding solvent: a water-acetone solution (1:1) for carrot bagasse, $80 \%(\mathrm{v} / \mathrm{v})$ cold acetone for apple and $100 \%(\mathrm{v} / \mathrm{v})$ methanol for banana, with constant magnetic stirring during $12 \mathrm{~h}$ for the first and $1 \mathrm{~h}$ for the last. Extracts were filtered through with a Whatman No. 1 filter paper and storage at room temperature on dark containers until further analysis. Total soluble phenolic compounds were determined by the method described by Singleton and Rossi (1965). Absorption was measurement at a wavelength of $765 \mathrm{~nm}$. The amount of total polyphenols was quantified using a calibration curve with gallic acid in the range of $0-0.1 \mathrm{mg} / \mathrm{mL}$. Results were expressed as $\mathrm{mg}$ of gallic acid equivalents (GAE)/100 $\mathrm{g}$ sample.

The antioxidant capacity of the polyphenols extract obtained from each byproduct was determined according to the methodology reported by Re et al. (1999). The antioxidant activity was reported in Trolox equivalents (TEAC) per $100 \mathrm{~g}$ of sample, according to:

$$
\text { Antioxidant activity }=\frac{\mathrm{Abs}_{\text {Control }}-\mathrm{Abs}_{\text {Sample }}}{\mathrm{Abs}_{\mathrm{Control}}} \times 100
$$

where $\mathrm{Abs}_{\mathrm{Control}}$ is the absorbance of control, and Abssample is the absorbance of the extract at $734 \mathrm{~nm}$.

Fermentation to determinate bacterial growth and acidification parameters Pediococcus pentosaceus UAM 22, a previously lactic acid bacteria reported as thermotolerant (Ramírez-Chavarín et al., 2010; Ramírez-Chavarín et al., 2013), was employed. Probiotic strain Lactobacillus rhamnosus GG was employed as probiotic control. The different by-products flours were 
employed as the carbon sources to determinate their influence on the growth and media acidification. Culture medium (Bustamante et al., 2006) was formulated with casein peptone $(0.5 \% \mathrm{w} / \mathrm{v})$, yeast extract $(0.3 \% \mathrm{w} / \mathrm{v})$, and carbon source. Carbon source was glucose $(1 \% \mathrm{w} / \mathrm{v}$, as Control) or byproducts flour (based on $1 \%$ of total soluble carbohydrates, determined by phenol-sulphuric method (Dubois et al., 1965). Samples of the different fermentations were taken during $10 \mathrm{~h}$ (one $\mathrm{h}$ each) to determinate bacterial growth and $\mathrm{pH}$.

\section{Bacterial growth and acidification parameters}

The bacterial growth employing the different co-products flours as carbon sources was evaluated counting the number of colonies employing the appropriate culture media incubated in anaerobic conditions during $24 \mathrm{~h}$ at 37 ${ }^{\circ} \mathrm{C}$.

The mean bacterial growth was determined according to Wiley et al. (2008), where $\mathrm{N}_{\mathrm{t}}=\mathrm{CFU} \mathrm{mL} \mathrm{L}^{-1}$ at the end of exponential phase and $\mathrm{N}_{0}=\mathrm{CFU} \mathrm{mL} \mathrm{m}^{-1}$ at the start of exponential phase at the time $\mathrm{h}$, according to:

$$
k=\frac{\log \mathrm{N}_{\mathrm{t}}-\log \mathrm{N}_{0}}{\log 2 \times \mathrm{t}}
$$

And the mean duplication time g (h) was calculated according to:

$$
g=\frac{1}{k}
$$

The acidification parameters calculated were $\mathrm{V}_{\max }$ (maximum acidification rate, $\mathrm{pH}$ units $\left.\times 10^{-3} \mathrm{~h}^{-1}\right)$, $\mathrm{pH} \mathrm{V}_{\max }\left(\mathrm{pH}\right.$ at $\mathrm{V}_{\max }$ ), and $\mathrm{t}_{\mathrm{V} \max }$ (time to reach $\mathrm{V}_{\max }$, h) (De Souza Oliveira et al., 2009).

\section{Prebiotic activity evaluation}

The prebiotic activity of each co-product flour was determined according to the relationship described by Huebner et al. (2007), considering the growth of lactic acid bacteria during fermentation $(\Delta \mathrm{N}: \mathrm{Nt}=10 \mathrm{~h}-\mathrm{N} 0=0 \mathrm{~h})$, using coproducts peel flours and glucose as carbon source, as follows:

$$
\text { Prebiotic Activity }=L A B \frac{\Delta N \text { prebiotic }}{\Delta N \text { glucose }}-\text { Enteric } \frac{\Delta N \text { prebiotic }}{\Delta N \text { glucose }}
$$

LAB employed was $P$. pentosaceus UAM 22 or L. rhamnosus GG counts, and Enteric is E. coli.

\section{Low pH tolerance and survival to simulated gastric acid conditions}

Lactic acid bacteria strain was reactivated and cells were collected by centrifugation $\left(5,000 \times \mathrm{g}\right.$ for $10 \mathrm{~min}$ at $\left.4^{\circ} \mathrm{C}\right)$. Cellular pellet was rinse two fold with sterile PBS ( $\mathrm{pH}$ 7.2) solution to determinate their low $\mathrm{pH}$ tolerance. The strain was inoculated in medium with prebiotics flours (banana and apple peels and carrot bagasse flour) and $\mathrm{pH}$ was adjusted to $0.5,1.0,2.0$, and 3.0 
before incubating during 1, 2 and $4 \mathrm{~h}$. Survival was quantified by plate counts reporting the survival percent (Ehrmann et al., 2002).

Survival in simulated gastric acid conditions was evaluated employing the activated strain $\left(\sim 10^{8} \mathrm{CFU} / \mathrm{mL}\right)$. After incubation bacteria was inoculated into a medium that simulated gastric juice adjusted at $\mathrm{pH} 1.0$ (carbon source $1 \%, 2.05 \mathrm{~g} / \mathrm{L} \mathrm{NaCl} ; 0.60 \mathrm{~g} / \mathrm{L} \mathrm{KH}_{2} \mathrm{PO} 4 ; 0.37 \mathrm{~g} / \mathrm{L} \mathrm{KCl} ; 0.05 \mathrm{~g} / \mathrm{L}$ porcine bile and $0.0133 \mathrm{~g} / \mathrm{L}$ pepsin), with prebiotic flours as carbon source. Survival was quantified by plate counts sampling at $0,30,60$ and $90 \mathrm{~min}$, diluting and inoculating in MRS plates, reporting the count of surviving microorganisms (Beumer et al., 1992).

\section{Experimental design}

The proposed model proposed to determinate the effect of the by-products peels flour as carbon source on the bacterial growth was:

$$
Y i j=\mu+\alpha i+\epsilon i
$$

where $Y_{i j k}$ represents the agro-industrial co-products flours composition, the parameters obtained from the fermentations (bacterial growth and acidification kinetics) with the $\mathrm{i}^{\text {th }}$ type of carbon source (banana peel flour, apple peel flour, carrot bagasse flour or glucose), $\alpha_{i}$ are the main effect for type of carbon source; $\epsilon_{i}$ is the residual error assuming a Normal distribution with $\bar{X}$ and $\sigma^{2}$, since the model as specified is over-parameterized and the parameters have to constrained by requiring them to set one parameter at least to zero (Der and Everitt, 2001). Time was included as second factor to analyse the simulated gastric conditions survival. Data were analysed with a analysis of variance (PROC ANOVA command) in SAS Software v. 8.0 (SAS Institute, Cary), determining significantly differences among means with the Duncan mean test.

\section{RESULTS AND DISCUSSION}

\section{Dietetic fiber content}

Table 1 presented the chemical composition results for the analysed agroindustrial co-products. The highest fiber content was detected in carrot bagasse, followed by banana peel and apple peel $(52.01 \%, 46.63 \%$ and $35.22 \%$, respectively). Carrot bagasse presented as well the higher insoluble fiber content (9.91\%). Techno-functional and physiological properties of both dietary fiber fractions, soluble and insoluble, are different according to the supply employed. The reduction in the glycemic response and plasma cholesterol attribute to soluble fiber is endorsed to their viscosity increase capacity, and the increase in faecal bulk together with the intestinal transit decrease are attributed to lower density and porosity of insoluble fiber (Elleuch et al., 2011). Total dietary fiber (TDF) content is close to the 
reported for other co-products like wheat bran (44\%), peach $(60 \%)$ and orange (38\%) (Grigelmo-Miguel and Martin-Belloso, 1999); orange Valencia (64\%) (Figuerola et al., 2005); carrot (30\%) (Laufenberg et al., 2003); and banana (47.99\%) (Jacometti et al., 2015).

The ratios of insoluble to soluble dietary fiber are shown in the Table 1. In most fruit and vegetable co-products this ratio approximates 2:1, although variations depend on the variety and maturity of the crop, especially for some apple varieties (Oreopolou and Tzia, 2007).

Table 1. Composition of dietary fiber, total phenols content and antioxidant activity for the agro-industrial co-products flours

\begin{tabular}{|l|c|c|c|}
\hline & Apple peel & Carrot bagasse & Banana peel \\
\hline $\begin{array}{l}\text { Total dietary fiber } \\
(\mathrm{g} / 100 \mathrm{~g})\end{array}$ & $35.22 \pm 0.49 \mathrm{c}$ & $52.00 \pm 0.81 \mathrm{a}$ & $46.63 \pm 0.27 \mathrm{~b}$ \\
\hline $\begin{array}{l}\text { Insoluble dietary fiber } \\
(\mathrm{IDF},(\mathrm{g} / 100 \mathrm{~g})\end{array}$ & $28.73 \pm 0.77 \mathrm{c}$ & $42.10 \pm 0.62 \mathrm{a}$ & $39.88 \pm 0.32 \mathrm{~b}$ \\
\hline $\begin{array}{l}\text { Soluble dietary fiber } \\
(\text { SDF, } g / 100 \mathrm{~g})\end{array}$ & $6.48 \pm 0.28 \mathrm{c}$ & $9.91 \pm 0.43 \mathrm{a}$ & $6.75 \pm 0.05 \mathrm{~b}$ \\
\hline IFD/SFD & 4.43 & 4.24 & 5.90 \\
\hline $\begin{array}{l}\text { Total phenol content }(\mathrm{mg} \\
\text { GAE/100 g sample) }\end{array}$ & $1669.02 \pm 4 \mathrm{a} .4 \mathrm{a}$ & $515.73 \pm 3.81 \mathrm{~b}$ & $147.02 \pm 1.44 \mathrm{c}$ \\
\hline $\begin{array}{l}\text { Antioxidant activity } \\
(\mu \mathrm{mol} \text { E Trolox/g sample) }\end{array}$ & $266.22 \pm 22.2 \mathrm{a}$ & $47.37 \pm 2.30 \mathrm{~b}$ & $30.93 \pm 1.40 \mathrm{c}$ \\
\hline
\end{tabular}

a, b, c Means in same row with same letter are not significantly different $(\mathrm{P}<0.05)$

\section{Total phenolic compounds and antioxidant capacity}

The results of bioactive compounds content in the studied samples are summarized in Table 1. A significantly $(\mathrm{P}<0.05)$ higher polyphenols content and antioxidant capacity were found in apple peel, followed by carrot bagasse and banana peel. The higher the total polyphenol content, the greater is the antioxidant activity (Goristein et al., 2002; Leontowicz et al., 2007). Someya et al. (2002) reported total phenolics were more abundant in banana peel than in pulp. There were differences in the activity antioxidant of extracts prepared by different solvents. González-Montelongo et al. (2010) reported that extracts of banana peel obtained with acetone:water were the most effective in inhibiting the oxidation of linoleic acid and subsequent bleaching of $\beta$-carotene, in comparison with the control. The extracts obtained with methanol:water, ethanol:water, methanol, ethanol or water had lower antioxidant activity in the $\beta$-carotene/linoleic acid system, $40-75 \%$ of the inhibition of extracts obtained with acetone: water. In this study the higher activity antioxidant was utilized methanol:water. The use of different solvent systems such as methanol (banana peel and apple peel) and acetone:water (carrot bagasse) was to obtain the maximum antioxidant activities of 
extracted polyphenols. Dufour et al. (2007) and Mohdaly et al. (2010) reported that extracts obtained using higher-polarity solvents were more effective radical scavengers than those obtained using lower-polarity solvents. Methanol showed slightly better characteristics than ethanol as a solvent for phenolic compounds, flavonoids and flavonols. Carrots contained mainly hydroxycinnamic acids. Phenolic content in different tissues decreased from peel, phloem to xylem, and antioxidant and radical scavenging activities decreased in same order as well (Bozalan and Karadeniz, 2011; Zhang and Hamauzu, 2004). The higher level of phenolic and antioxidant properties in carrot peel treated as the waste in the processing industry could be considered for value-added. Fruits and vegetables peels contain higher amounts of total phenolics compared to the edible portions. The wide variations in the total phenolics contents of the different fruits or vegetables, or even for the same fruits or vegetables, can be attributed to the complexity of these groups of compounds, and the methods of extraction and analysis (Balasundram et al., 2006). Several polyphenols have been shown to inhibit the growth and adhesion of gut pathogens to a human gut cell line, and to enhance the proliferation and adhesion of probiotic L. rhamnosus (Parkar et al., 2008).

\section{Bacterial growth parameters and acidification parameters}

When glucose and apple peel flour were employed as carbon source in $P$. pentosaceus fermentations, significantly $(\mathrm{P}<0.05)$ higher values for mean growth rate were obtained, banana peel flour resulted in the lower ones. In same way, significantly $(\mathrm{P}<0.05)$ lower mean duplication times values for glucose and apple peel flour fermentations was obtained (Table 2).

Similar tendency was observed with L. rhamnosus, with significantly $(\mathrm{P}<0.05)$ higher values for mean growth rate and significantly $(\mathrm{P}<0.05)$ lower mean duplication times values in fermentations with glucose and apple peel flour. No growth was observed when banana peel flour was employed as carbon source in fermentations with L. rhamnosus (Table 2).

For the acidification parameters, in $P$. pentosaceus fermentations employing glucose or apple peel flour resulted in significantly $(\mathrm{P}<0.05)$ higher maximum acidification rate (Vmax) values, followed by the carrot bagasse samples. In same manner, the $\mathrm{pH}$ at $\mathrm{Vmax}$ was significantly $(\mathrm{P}<0.05)$ higher with glucose and apple peel flour as carbon source. Consequently, the time to reach the maximum acidification rate was significantly $(\mathrm{P}<0.05)$ lower in fermentations with glucose or apple peel flour. Banana peel flour resulted in lower growth and acidification for $P$. pentosaceus (Table 2).

In L. rhamnosus fermentations, glucose or apple peel flour fermentations resulted in significantly $(\mathrm{P}<0.05)$ higher $V \max$ values, with significantly $(\mathrm{P}<0.05)$ higher $\mathrm{pH}$ at $\mathrm{Vmax}$ values. Significantly $(\mathrm{P}<0.05)$ lower time to 
reach the maximum acidification rate was obtained as well with glucose or apple peel flour. No growth was observed when banana peel flour was employed as carbon source (Table 2).

The ability to utilize one prebiotic is strain-dependent conditioned on their ability to depolymerizing capacity (Yeo and Liong, 2010). Lactic acid bacteria are capable to metabolize other carbon sources, depending on the chemical structure, polymerization degree and the type and composition of the monomeric units. Maximum specific growth rates are observed with disaccharides and oligosaccharides as compared to monosaccharide, confirming differences carbohydrate utilization abilities and kinetics by different strains, as Parra-Matadamas et al. (2015) reported higher growth rate when grapefruit peel flour was employed as carbon source. The simultaneous production of several different glycosyl hydrolases and the cometabolism of indigestible di- and oligosaccharides represent a selective advantage over other colonic bacteria for the utilization of the intestinal fermentable carbon sources (Amaretti et al., 2006).

Table 2. Effect of different carbon sources on bacterial growth parameters for $P$. pentosaceus and L. rhamnosus

\begin{tabular}{|c|c|c|c|c|c|}
\hline $\begin{array}{c}\text { Carbon } \\
\text { source }\end{array}$ & $\mathbf{k}\left(\mathbf{h}^{-1}\right)$ & g (h) & $\begin{array}{l}\mathrm{Vmax}(\mathrm{pH} \\
\left.\times 10^{-3} / \mathrm{min}\right)\end{array}$ & $\mathbf{p H}_{\text {Vmax }}$ & $t_{V \max }(h)$ \\
\hline \multicolumn{6}{|c|}{ P.pentosaceus } \\
\hline Glucose & $1.40 \pm 0.04 \mathrm{a}$ & $0.62 \pm 0.04 \mathrm{c}$ & $4.45 \pm 0.04 a$ & $5.72 \pm 0.2 \mathrm{a}$ & $4.72 \pm 0.7 \mathrm{c}$ \\
\hline Apple peel & $1.45 \pm 0.04 \mathrm{a}$ & $0.65 \pm 0.04 \mathrm{c}$ & $4.39 \pm 0.01 \mathrm{a}$ & $5.66 \pm 0.3 a$ & $4.89 \pm 0.1 \mathrm{c}$ \\
\hline $\begin{array}{l}\text { Carrot } \\
\text { bagasse }\end{array}$ & $1.25 \pm 0.01 \mathrm{~b}$ & $0.70 \pm 0.01 b$ & $3.97 \pm 0.10 \mathrm{~b}$ & $5.15 \pm 0.2 b$ & $5.71 \pm 0.2 b$ \\
\hline $\begin{array}{l}\text { Banana } \\
\text { peel }\end{array}$ & $1.23 \pm 0.03 \mathrm{c}$ & $0.85 \pm 0.00 \mathrm{a}$ & $3.78 \pm 0.30 \mathrm{c}$ & $4.85 \pm 0.6 \mathrm{c}$ & $7.70 \pm 0.1^{\mathrm{a}}$ \\
\hline \multicolumn{6}{|c|}{ L. rhamnosus } \\
\hline Glucose & $1.36 \pm 0.07 \mathrm{a}$ & $0.74 \pm 0.04 \mathrm{~b}$ & $4.50 \pm 0.10 \mathrm{a}$ & $5.29 \pm 0.03 \mathrm{a}$ & $4.97 \pm 0.30 \mathrm{~b}$ \\
\hline Apple peel & $1.25 \pm 0.03 \mathrm{a}$ & $0.80 \pm 0.08 \mathrm{~b}$ & $4.20 \pm 0.20 \mathrm{a}$ & $5.09 \pm 0.10 \mathrm{a}$ & $4.82 \pm 0.20 \mathrm{~b}$ \\
\hline $\begin{array}{l}\text { Carrot } \\
\text { bagasse }\end{array}$ & $1.06 \pm 0.05 b$ & $0.94 \pm 0.00 \mathrm{a}$ & $3.00 \pm 0.20 \mathrm{~b}$ & $4.95 \pm 0.20 \mathrm{~b}$ & $5.95 \pm 0.30^{\mathrm{a}}$ \\
\hline
\end{tabular}

$\mathrm{a}, \mathrm{b}, \mathrm{c}$ Means in same column with same letter are not significantly different $(\mathrm{P}<$ 0.05 ) for each microorganism

\section{Prebiotic activity evaluation}

The prebiotic activity was significantly $(\mathrm{P}<0.05)$ higher for apple peel flour, followed by carrot bagasse flour, in fermentations with $P$. pentosaceus. When L. rhamnosus was tested, significantly $(\mathrm{P}<0.05)$ higher prebiotic values were obtained with apple peel flour, followed as well by carrot bagasse flour (Table 3). L. rhamnosus presented no growth with banana peel flour. 
Prebiotic activity reflects the ability of a given substrate to support the growth of a probiotic in relation to other microorganism, a pathogen. The relative growth on a non-prebiotic substrate, such as glucose, indicates changes in bacterial population, substrate assimilation and growth rate, assigning a positive or negative effect as the calculated index of a specific strain of bacteria (Huebner et al., 2007). At the experimental conditions, P. pentosaceus obtained higher prebiotic activity scores, related to higher growth and acidification parameters than L. rhamnosus GG, indicating a better assimilation of the fermentable carbohydrates present in the peel flours. Different microorganisms react differently to different sugars. For same $P$. pentosaceus UAM 22 strain, Díaz-Vela et al. (2013) reported similar prebiotic activity score results of 0.33 and 0.32 for cactus pear peel flour and pineapple peel flour, respectively. In same manner, garlic, shallot or onion extracts presented higher prebiotic score (close 2.0), but with germinated rice extract the prebiotic score was low (0.20) for $L$. acidophilus (Moongngamn et al., 2011).

Table 3. Prebiotic activity of the different carbon sources

\begin{tabular}{|l|l|l|}
\hline \multirow{2}{*}{ Carbon source } & \multicolumn{2}{|l|}{ Lactic acid bacteria strain } \\
\cline { 2 - 3 } & P.pentosaceus & L. rhamnosus \\
\hline Apple peel & $0.42 \pm 0.04 \mathrm{a}$ & $0.43 \pm 0.08 \mathrm{a}$ \\
\hline Carrot bagasse & $0.38 \pm 0.07 \mathrm{~b}$ & $0.40 \pm 0.11 \mathrm{~b}$ \\
\hline Banana peel & $0.28 \pm 0.03 \mathrm{c}$ & No growth \\
\hline
\end{tabular}

$\mathrm{a}, \mathrm{b}, \mathrm{c}$ Means in same column with same letter are not significantly different $(\mathrm{P}<$ $0.05)$

Low $\mathrm{pH}$ tolerance and survival to simulated gastric acid conditions

At the lowest $\mathrm{pH}$ employed (0.50), there was no detectable growth with any of the agro-industrial co-products flours tested. At $\mathrm{pH}$ 1.0, employing glucose or apple peel flour the growth during the first hour was scare (35\%). After this period, acid tolerance along the prebiotic presence increased the acid resistance, increasing the bacteria survive to 67 and $73 \%$ for 2 and $4 \mathrm{~h}$, respectively. Carrot bagasse incubation presented a nearly constant growth during the $4 \mathrm{~h}$ period (63-67\% survive). No growth was detected when banana peel flour was employed in the acid incubation. At $\mathrm{pH} 2.0$, the surviving percent was higher and more constant than at $\mathrm{pH} 2.0$, with a survival rate of $68 \%$ for glucose and apple peel flour, $65 \%$ for carrot bagasse flour and $61 \%$ for banana peel flour. When the $\mathrm{pH}$ was 3.0, P. pentosaceus survival was higher when glucose or apple peel flour was employed (99 and $97 \%$, respectively). The growth at this acidic condition with carrot bagasse flour and banana peel flour were as well higher as compared to lower $\mathrm{pH}$, with $91 \%$ and $89 \%$, respectively. For the incubation at simulated gastric acid conditions, the use of glucose or apple peel flour resulted in significantly 
$(\mathrm{P}<0.05)$ higher survival rate as compared to carrot bagasse flour or banana peel flour. In same manner, the growth of $P$. pentosaceus at the experimental conditions employed with the different carbon sources increased with incubation time, being significantly $(\mathrm{P}<0.05)$ higher after $90 \mathrm{~min}$ (Table 4). Boke et al. (2010) reported a possible relation between exopolysaccharides (EPS) production and resistance to bile salts and tolerance to low $\mathrm{pH}$. PérezChabela et al. (2013) and Diaz-Vela et al. (2015) reported that same $P$. pentosaceus UAM22 strain produced exopolysaccharide when was inoculated in cooked meat batters. The resistance to low acid condition of the agroindustrial co-products flours firm up the prebiotic of these ingredients as non-digestible compounds that stimulate the growth of beneficial bacteria in the gastro-intestinal tract.

Table 4. P. pentosaceus $(\log \mathrm{UFC} / \mathrm{mL})$ under simulated gastric conditions with different carbon sources

\begin{tabular}{|l|c|c|c|c|}
\hline \multirow{2}{*}{$\begin{array}{c}\text { Carbon } \\
\text { source }\end{array}$} & \multicolumn{4}{|c|}{ Time (min) } \\
\cline { 2 - 5 } & $\mathbf{0}$ & $\mathbf{3 0}$ & $\mathbf{6 0}$ & $\mathbf{9 0}$ \\
\hline Glucose & $4.16 \pm 0.4 \mathrm{~A}, \mathrm{c}$ & $4.10 \pm 0.3 \mathrm{~A}, \mathrm{~b}$ & $4.23 \pm 0.2 \mathrm{~A}, \mathrm{~b}$ & $4.76 \pm 0.3 \mathrm{~A}, \mathrm{a}$ \\
\hline Apple peel & $3.94 \pm 0.5 \mathrm{~A}, \mathrm{c}$ & $4.11 \pm 0.7 \mathrm{~A}, \mathrm{~b}$ & $4.06 \pm 0.5 \mathrm{~A}, \mathrm{~b}$ & $4.77 \pm 0.4 \mathrm{~A}, \mathrm{a}$ \\
\hline Carrot bagasse & $3.88 \pm 0.3 \mathrm{~B}, \mathrm{c}$ & $4.15 \pm 0.5 \mathrm{~B}, \mathrm{~b}$ & $3.91 \pm 0.83 \mathrm{~B}, \mathrm{~b}$ & $4.71 \pm 0.8 \mathrm{~B}, \mathrm{a}$ \\
\hline Banana peel & $3.54 \pm 0.6 \mathrm{C}, \mathrm{c}$ & $3.74 \pm 0.9 \mathrm{C}, \mathrm{b}$ & $3.26 \pm 0.9 \mathrm{C}, \mathrm{b}$ & $4.16 \pm 0.5 \mathrm{C}, \mathrm{a}$ \\
\hline
\end{tabular}

A, B Means in same row with same letter are not significantly different $(\mathrm{P}<0.05)$ for carbon source

$\mathrm{a}, \mathrm{b}$ Means followed by the same superscripts in a row are not significantly different $(\mathrm{P}<0.05)$ for incubation time.

\section{CONCLUSION}

Agro-industrial co-products demonstrate to be sources of fiber and phenolic compounds, like natural antioxidants. Apple bagasse flour presented a similar performance as compared to glucose to promote the growth of lactic acid bacteria. Banana peel flour obtained poor results as prebiotic. In same manner, apple peel flour and carrot bagasse flour enhanced the low $\mathrm{pH}$ and gastric acid conditions of $P$. pentosaceus, demonstrating their prebiotic capacity. Fruit processing co-products can be considered an effective and cheap prebiotic source.

\section{REFERENCES}

1. Amaretti, A., Tamburini, E., Bernardi, T., Pompei, A., Zanoni, S., Vaccari, G., Matteuzzi, D., \& Rossi, M. (2006). Substrate preference of Bifidobacterium adolescentis MB 239: compared growth on single and 
mixed carbohydrates. Applied Microbiology Biotechnology, 73, 654-662. DOI: $10.1007 / \mathrm{s} 00253-006-0500-9$.

2. AOAC (1999). Official Methods of Analysis of AOAC International. 16th edition. AOAC International, Gaithersburg.

3. Balasundram, N., Sundram, K., \& Samman, S. (2006). Phenolic compounds in plants and agroindustrial by-products: antioxidant activity, occurrence, and potential uses. Food Chemistry, 99, 121-203. DOI: doi:10.1016/j.foodchem.2005.07.042.

4. Beumer, R.R., De Vries, J., \& Rombouts, F.M. (1992). Campylobacter jejuni non-culturable coccoid cells. International Journal of Food Microbiology, 15 (1-2), 153-163. DOI: 10.1016/0168-1605(92)90144-R.

5. Boke, H., Aslim, B., \& Alp, G. (2010). The role of resistance to bile salts and acid tolerance of exopolysaccharides (EPS) produced by yogurt starter bacteria. Archives of Biological Sciences, 62 (2), 323-328. DOI: 10.2298/ABS1002323B.

6. Bozalan, N.K., \& Karadeniz, F. (2011). Carotenoid profile, total phenolic content, and antioxidant activity of carrots. International Journal of Food Properties, 14 (5),1060-1068. DOI:10.1080/10942910903580918.

7. Bustamante, P., Mayorga, L., Ramírez, H., Martínez, P., Barranco, E. \& Azaola, A. (2006). Evaluación microbiológica de compuestos con actividad prebiótica. Revista Mexicana de Ciencias Farmacéuticas, 37, $5-10$.

8. Cheynier, V. (2005). Polyphenols in foods are more complex than often thought. The American Journal of Clinical Nutrition, 81(1), 223S-229S.

9. De Souza Oliveira, R.P., Perego, P., Converti, A., \& De Oliveira, M.N. (2009). Growth and acidification performance of probiotics in pure culture and co-culture with Streptococcos thermophilus: the effect of inulin. LWT-Food Science and Technology, 42, 1015-1021. DOI: 10.1016/j.lwt.2009.01.002.

10. Delzenne, N.M. \& Roberfroid, M.B. (1994). Physiological effects of non-digestible oligosaccharides. LWT-Food Science and Technology, 27(1), 1-6. DOI: 10.1006/fstl.1994.1001.

11. Der G. \& Everitt, B.S. (2001). A Handbook of Statistical Analyses using SAS. CRC Press, London, 101-116.

12. Díaz Vela, J., Totosaus, A., \& Pérez-Chabela, M.L. (2015). Integration of agroindustrial by-products as functional food ingredients: cactus pear (Opuntia ficus indica) flour and pineapple (Ananas comosus) peel flour as fiber source in cooked sausages inoculated with lactic acid bacteria. Journal of Food Processing and Preservation, 39(6), 2630-26358. DOI: DOI: $10.1111 /$ jfpp. 12513.

13. Díaz-Vela, J., Totosaus, A., Cruz-Guerrero, A. E., \& Pérez-Chabela, M.L. (2013). In vitro evaluation of the fermentation of added-value agroindustrial by-products: cactus pear (Opuntia ficus-indica L.) peel and pineapple (Ananas comosus) peel as functional ingredients. 
International Journal of Food Science and Technology, 48, 1460-1467. DOI: 10.1111/ijfs.12113.

14. Dubois, M., Gilles, K.A., Hamilton, J.K., Rebers, P., \& Smith, F. (1956). Colorimetric method for determination of sugars and related substances. Analytical Chemistry, 28, 350-356. DOI: 10.1021/ac60111a017.

15. Dufour, D., Pichette, A., Mshildadze, V., Bradette-Hehert, M. E., Lavoie, S., Longtin, A., Laprise, C. \& Legault, J. (2007). Antioxidant, anti-inflammatory and anticancer activities of methanolic extracts from Ledum groenlandicum Retzius. Journal of Ethnopharmacology, 111 (1), 22-28. DOI:10.1016/j.jep.2006.10.021.

16. Ehrmann, M.A., Kurzak, P., Bauer, J., \& Vogel, R. F. (2002). Characterization of lactobacilli towards their use as probiotic adjuncts in poultry. Journal of Applied Microbiology, 92(5), 956-975. DOI: 10.1046/j.1365-2672.2002.01608.x.

17. Elleuch, M., Bedigian, D., Roiseux, O., Besbes, S., Blecker, C. \& Attia, H. (2011). Dietary fibre and fibre-rich by-products of food processing: characterisation, technological functionality and commercial applications: A review. Food Chemistry, 124 (2), 411-421. DOi: 10.1016/j.foodchem.2010.06.077.

18. Figuerola, F., Hurtadi, M.L., Estévez, A.M., Chiffelle, I., \& Asenjo, F. (2005). Fibre concentrates from apple pomace and citrus peel as potential fibre sources for food enrichment. Food Chemistry, 91 (3), 395401. DOI: 10.1016/j.foodchem.2010.06.077.

19. Gibson, G.R., Probert, H.M., Loo, J.V., Rastall, R.A., Roberfroid, M.B. 2004. Dietary modulation of the human colonic microbiota: updating the concept of prebiotics. Nutrition Research Reviews, 17(2): 259-275. DOI: 10.1079/NRR200479.

20. González-Montelongo, R., Lobo, M.G., \& González, M. (2010). Antioxidant activity in banana peel extracts: Testing extraction conditions and related bioactive compounds. Food Chemistry, 119, 1030-1039. DOi: 10.1016/j.foodchem.2009.08.012.

21. Gorinstein, S., Martin-Belloso, O., Lojek, A., Cíz, M., Soliva-Fortuny, R., Park, Y.-S., Caspi, A., Libman, I. \& Trakhtenberg, S. (2002). Comparative content of some phytochemicals in Spanish apples, peaches and pears. Journal of the Science of Food and Agriculture, 82 (10), 1166-1170. DOI: $10.1002 /$ jsfa.1178.

22. Grigelmo-Miguel, N., \& Martin-Belloso, O. (1999). Comparison of dietary fibre from by-products of processing fruits and greens and from cereals. LWT-Food Science and Technology, 32 (8), 503-508. DOI: 10.1006/fstl.1999.0587.

23. Huebner, J., Wehling, R. I., \& Hutkins, R.W. (2007). Functional activity of commercial prebiotics. International Dairy Journal, 17, 770-775. DOI: 10.1016/j.idairyj.2006.10.006.

24. Jacometti, G.A., Mello, L.P.R.F., Nascimento, P.H.A., Sueiro, A.C., Yamashita, F., \& Mali, S. (2015). The physicochemical properties of 
fibrous residues from the agro industry. LWT-Food Science and Technology, 62(1), 138-143. DOI: 10.1016/j.lwt.2015.01.044.

25. Larrauri, J.A. (1999). New approaches for the preparation of high dietary fibre powders from fruit by-products. Trends in Food Science and Technology, 10 (1), 3-8. DOI: 10.1016/S0924-2244(99)00016-3.

26. Laufenberg, G., Kunz, B., \& Nystroem, M. (2003). Transformation of vegetable waste into value added products: (A) the upgrading concept; (B) practical implementations. Review. Bioresource Technology, 87 (2), 167-198. DOI: 10.1016/S0960-8524(02)00167-0.

27. Leontowickz, M., Leontowickz, H., Goristein, S., Martin-Belloso, O., \& Trakhtenberg S. (2007). Apple peels and pulp as a source of bioactive compounds and their influence on digestibility and lipid profile in normal and atherogenic rats. Medycyna Weterynaryjna, 63 (11), 14341436.

28. Manach, C., Williamson, G., Morand, C., Scalbert, A., \& Rémésy, C. (2005). Bioavailability and bioefficacy of polyphenols in humans. I. Review of 97 bioavailability studies. The American Journal of Clinical Nutrition, 81(1), 230S-242S.

29. Marlett, J.A., McBurney, M.I., \& Slavin, J.L. (2002). Position of the American Dietetic Association: Health implications of dietary fiber. Journal of the American Dietetic Association, 102(7), 993-1000. DOI: 10.1016/j.jada.2008.08.007.

30. Martínez, R., Torres, P., Meneses, M.A., Figueroa, J.G., Pérez-Álvarez, J.A. \& Viuda-Martos, M. (2012). Chemical, technological and in vitro antioxidant properties of mango, guava, pineapple and passion fruit dietary fibre concentrate. Food Chemistry, 135, 1520-152. DOI: 10.1016/j.foodchem.2012.05.057.

31. Moongngarm, A., Trachoo,N., \& Sirigungwan, N. (2011). Low molecular weight carbohydrates, prebiotic content, and prebiotic activity of selected food plants in Thailand. Advance Journal of Food Science and Technology, 3(4), 269-274.

32. Oreopoulou, V., \& Tzia, C. (2007). Utilization of plant by-products for the recovery of proteins, dietary fibers, antioxidants and colorants. In: Utilization of By-Products and Treatment of Waste in the Food Industry. Oreopoulou, V., \& Russ, W. (eds.) New York, Springer, 209-232.

33. Parkar, S. G., Stevenson, D.E., \& Skinner, M.A. (2008). The potential influence of fruit polyphenols on colonic microflora and human gut health. International Journal of Food Microbiology, 124 (3), 295-298. DOI: 10.1016/j.ijfoodmicro.2008.03.017.

34. Parra-Matadamas, A., Mayorga-Reyes, L., \& Pérez-Chabela, M.L. (2015). In vitro fermentation of agroindustrial by-products: grapefruit albedo and peel, cactus pear peel and pineapple peel by lactic acid bacteria. International Food Research Journal, 22(2), 859-865.

35. Pérez-Chabela M.L., J. Díaz-Vela, C.V. Menéndez, \& Totosaus, A. (2013). Improvement of moisture stability and textural properties of fat 
and salt reduced cooked sausages by inoculation of thermotolerant lactic acid bacteria. International Journal of Food Properties, 16(8), 17891808. DOI:10.1080/10942912.2011.608472.

36. Ramírez-Chavarín, N.L., Wacher, C., Eslava-Campos, C.A., \& PérezChabela, M.L. (2013). Probiotic potential of thermotolerant lactic acid bacteria strains isolated from cooked meat products. International Food Research Journal, 20 (2), 991-1000.

37. Ramírez-Chavarín, N.L., Wacher-Rodarte, C. \& Pérez-Chabela, M.L. (2010). Characterization and identification of thermotolerant lactic acid bacteria isolated from cooked sausages as bioprotective cultures. Journal of Muscle Foods, 21(3), 585-596. DOI: 10.1111/j.17454573.2009.00206.x.

38. Re, R., Pellegrini, N., Proteggente, A., Pannala, A., Yang, M., \& RiceEvans, C. (1999). Antioxidant activity applying and improved ABTS radical cation decolorization assay. Free Radical Biology and Medicine, 26(9-10), 1231-1237. DOI: :10.1016/S0891-5849(98)00315-3.

39. Roberfroid, M. (2007). Prebiotics: The concept revisited. The Journal of Nutrition, 137(3), 830S-837S.

40. Sánchez-Zapata, E., Fuentes-Zaragoza, E., Fernández-López, J., Sendra, E., Sayas, E., Navarro, C., \& Pérez-Alvarez, J.A. (2009). Preparation of dietary fiber powder from tiger nut (Cyperus esculentus) milk ("Horchata") by products and its physicochemical properties. Journal of Agricultural and Food Chemistry, 57, 7719-7725. DOI: 10.1021/jf901687r.

41. Singleton, V. L., \& Rossi, J.A. (1965). Colorimetry of total phenolics with phosphomolybdic-phosphotungstic acid reagents. American Journal of Enology and Viticulture, 16 (48), 144-158.

42. Someya, S., Yoshiki, Y., \& Okubo, K. (2002). Antioxidant compounds from bananas (Musa Cavendish). Food Chemistry, 79, 351-354. DOI: 10.1016/S0308-8146(02)00186-3.

43. Trowell, H. (1974). Definitions of fibre. The Lancet, 303, 503-505. DOI: 10.1016/S0140-6736(74)92802-5.

44. Willey, J., Sherwood, I.M., \& Woolverton, C.J. (2008). El crecimiento Microbiano. In: Microbiología de Prescott, Harley and Klein. Wiley, J., Sherwood, I.M. \& Woolverton, C.J. (eds). Mc Graw Hill: Madrid, 119148.

45. Yeo, S-K., \& Liong, M.-T. (2010). Effect of prebiotics on viability and growth characteristics of probiotics in soymilk. Journal of Food Science and Agriculture, 90, 267-275. DOI: 10.1002/jsfa.3808.

46. Zhang, D., \& Hamauzu, Y. (2004). Phenolic compounds and their antioxidant properties in different tissues of carrots (Daucus carota L.). Journal of Food Agriculture and Environment, 2 (1), 95-100. 